\title{
Isotype-specific Antibody Responses to Rhodococcus equi in Foals on a Horse-breeding Farm with a Persistent Incidence of R. equi Infection
}

\author{
Shinji TAKAI ${ }^{1 *}$, Izumi NAKATA ${ }^{1}$, Naoto FUJII $^{1}$, Yoshinori KIMURA ${ }^{2}$, Yukako SASAKI ${ }^{1}$, \\ Tsutomu KAKUDA ${ }^{1}$, Shiro TSUBAKI ${ }^{1}$, Takashi KONDO ${ }^{3}$ and Takeo SUGIURA ${ }^{3}$ \\ ${ }^{1}$ Department of Animal Hygiene, School of Veterinary Medicine and Animal Sciences, Kitasato University, \\ Towada, Aomori 034-8628, 'Bloodhorse Breeders' Association, Shichinohe Stalion Station, Shichinohe, \\ Aomori 039-2501, ${ }^{3}$ Epizootic Research Station, Equine Research Institute, Japan Racing Association, \\ Kokubunji-machi, Tochigi 329-0412, Japan
}

Isotype-specific antibody responses in 13 foals to Rhodococcus equi were studied during the first 20 weeks of life on a horse-breeding farm with a persistent incidence of $R$. equi infection. The levels of immunoglobulin (Ig) classes and Ig G subclasses specific for R. equi antigens in the 13 foal sera were determined by ELISA and Western immunoblotting. Kinetics of the total amount of IgG and the number of WBC in the blood of 13 foals were also monitored. Soluble extract from R. equi strain ATCC 6939 was used as a routine EISA antigen. During the observation period, 8 of the 13 foals showed $>0.3$ OD value against ATCC 6939 antigen by a routine ELISA, which was tentatively fixed to be positive on the basis of readings made of healthy horse sera in previous studies. R. equi-specific IgGa was predominantly detected in these foals at 6 to 10 weeks after birth by ELISA with Tween 20-extracted ATCC 6939 antigens. Specific serum IgGb, and IgA were also detected, but they showed lower titers than IgGa antibodies in the foals. Specific $\operatorname{Ig} G(T), \operatorname{Ig} G c$ and IgM was present consistently at low levels in most foals. On the other hand, IgGa and IgGb antibodies specific for 15- to 17-kDa antigens (VapA) were detected by immunoblotting at 5 to 7 weeks of age in most foals. Out of the 13 foals, 3 foals had a serum IgG concentrations less than 1,000 mg/dl (650 to $900 \mathrm{mg}$ ) dl) at the first week of birth. WBC counts tended to increase by 8 weeks with age in all foals. Virulent R. equi was isolated from the feces of foals during this study. This study suggests that R. equi-specific IgGa was predominantly measured by ELISA, and VapA-specific IgGa and $I g G b$ were predominantly detected by immunoblotting in foals naturally exposed to $R$. equi on a farm with a persistent incidence of $R$. equi infection.

Key words: Rhodococcus equi, isotype, antibody, foals
J. Equine Sci.

Vol. 13, No. 2

pp. 63-70, 2002
Rhodococcus equi is one of the most important bacterial pathogens in young foals. Infections caused by this organism are characterized by chronic, suppurative bronchopneumonia and enteritis associated with a high mortality rate $[2,13,20]$. We previously reported that the 15 - to $17-\mathrm{kDa}$ virulenceassociated protein antigens (VapA) of $R$. equi were associated with virulence in mice, and that the presence of an $85-\mathrm{kb}$ or a $90-\mathrm{kb}$ plasmid was essential for

This article was accepted June 20, 2002.

${ }^{*}$ Corresponding author. virulence and the expression of VapA [26, 30]. These virulence-associated antigens and virulence plasmids have been used as epidemiological markers to identify virulent $R$. equi isolates from horses and their environment by Western blot (immunoblot) assay with a monoclonal antibody and plasmid profiles [21, 28, 31]. In a survey of the prevalence of virulent $R$. equi at horse-breeding farms in Japan, $R$. equi was isolated from almost all soil samples, at numbers of $10^{2}$ to $10^{5}$ per gram of soil [21]. Although the majority of these isolates did not contain virulence plasmids and were avirulent, some of these farms were contaminated to 
various degrees with virulent $R$. equi in accordance with the incidence of infection [20,21, 28].

Inhalation of dust particles laden with virulent $R$. equi is the major route of pneumonic infection [13, 34]. Ingestion of the organism is a significant route of exposure, and likely also of immunization [22], since the organism multiplies in the intestines of the foal up to about three months of age, reaching numbers up to $10^{5} / \mathrm{g}$ of feces [29]. Pneumonic foals swallow infected sputum, and virulent bacteria so swallowed can multiply in their intestines, so that the manure of affected foals is most likely a major source of progressive contamination of the environment with virulent organisms [20]. Foals bred on farms with endemic infection can be open to multiple exposures to large numbers of virulent $R$. equi [21, 26]. Our previous study demonstrated that serum antibody response to VapA occurred naturally in every foal in association with the quantitative changes in fecal $R$. equi during the first 1 to 3 months of life, suggesting that intestinal virulent $R$. equi might be the most important source of antigenic stimulation in foals from contaminated farms [22].

It is well established that the functional activities of antibodies are dependent on their isotypes [4], and that immunoglobulin ( $\mathrm{Ig}$ ) isotype responses to infectious organisms are not randomly distributed [8]. Recent characterization of horse IgG subisotypes by using monoclonal antibodies (mAbs) has demonstrated four well-defined equine IgG isotypes, IgGa, IgGb, IgGc and IgG(T) [19], which occupied approximately $9,77,1$ and 13 percent of serum, respectively [15].

The purpose of this study is to analyze the Ig subclass (isotype) reactivity of anti- $R$. equi antibodies in 13 foals during the first 20 weeks of life on a horse-breeding farm with a persistent incidence of $R$. equi infection by enzyme-linked immunosorbent assay and Western immunoblotting with changes in the $\operatorname{IgG}$ concentration, a WBC count and the prevalence of virulent $R$. equi in the feces of foals.

\section{Materials and Methods}

\section{Blood and sera from foals}

Sera from 13 Thoroughbred foals on a farm in Aomori, which revealed recurrent incidences of $R$. equi infection, were collected 6 to 11 times at one week intervals after birth from March to August in 1998. Sera from the dams of the 13 foals were collected once immediately after foaling.

Blood samples were collected in EDTA vacuum tubes to determine erythrocyte and total leucocyte counts. The serum IgG concentration was determined by a nephelometry assay (Nissan Gousei, Tokyo, Japan).

\section{ELISA}

ELISA antigen was prepared from R. equi ATCC 6939 as described previously [24]. Briefly, strain ATCC 6939 was grown on brain heart infusion agar. Bacteria were harvested after 5 days of incubation at $38^{\circ} \mathrm{C}$. R. equi $(2$ $\mathrm{g}$ [wet weight]) was suspended in $10 \mathrm{ml}$ of $0.0125 \mathrm{M}$ sodium phosphate buffer ( $\mathrm{pH} 7.4$ ) containing $0.1 \%$ (wt/vol) Tween 20 , incubated at $37^{\circ} \mathrm{C}$ for $90 \mathrm{~min}$ in a water bath with agitation and centrifuged at $20,000 \times \mathrm{g}$ for $30 \mathrm{~min}$ at $4^{\circ} \mathrm{C}$. The supernatant was adjusted to 1.0 $\mu \mathrm{g}$ of protein $/ \mathrm{m} l$ in carbonate-bicarbonate buffer $(\mathrm{pH}$ 9.6) and used as an antigen.

The ELISA used was based on that of Takai et al. [25]. Optimal dilutions of reagents were obtained by checkerboard titrations. Peroxidase conjugated to antihorse IgGa (prepared in goats, heavy chain specific, Bethyl Laboratories Inc., Montgomery, Texas), antihorse IgGb (prepared in goats, heavy chain specific, Bethyl Laboratories Inc), anti-horse IgGc (prepared in goats, heavy chain specific, Bethyl Laboratories Inc), anti-horse $\operatorname{IgG}(\mathrm{T})$ (prepared in goats, heavy chain specific, Bethyl Laboratories Inc), anti-horse IgA (prepared in goats, $\alpha$-chain specific, Bethyl Laboratories Inc), anti-horse IgM (prepared in goats, $\mu$ chain specific, Bethyl Laboratories Inc), and anti-horse IgG (prepared in goats, heavy and light chains specific, Bethyl Laboratories Inc), were used.

\section{Gel electrophoresis and Western immunoblot analysis}

Whole-cell antigens of strain ATCC 33701, which were prepared by harvesting bacteria grown at $38^{\circ} \mathrm{C}$ for $48 \mathrm{hr}$ in brain heart infusion broth and solubilizing the bacteria in sodium dodecyl sulfate (SDS) reducing buffer, were separated by SDS-polyacrylamide gel electrophoresis [26], and electrotransferred to nitrocellulose sheets. A strip of the sheet was incubated at $37^{\circ} \mathrm{C}$ for $2 \mathrm{hr}$ with each test serum (diluted in PBS with 10\% Block Ace 1:100). The strips were washed three times for $10 \mathrm{~min}$ in washing buffer. Bound foal immunoglobulin was detected by incubating the strips with monoclonal antibodies to IgGa (F12a1A5), IgGb (F12b6E8), IgGc (F14c10G12), IgG(T) (F6T3A5), IgM (F13M6D6), and IgA (F9A) which were produced by 
Sugiura et al. [19]. After a series of titrations, the optimum dilutions were as follows: IgGa (F12a1A5), 1/ 4,000; IgGb (F12b6E8), 1/4,000; IgGc (F14c10G12), 1/ 2,000; IgG(T) (F6T3A5), 1/2,000; IgM (F13M6D6), 1/ 2,000; and IgA (F9A) $1 / 2,000$. These monoclonal antibodies were detected by incubating the strips with rabbit anti-mouse immunoglobulin $\mathrm{G}$ conjugated with horse-radish peroxidase (diluted in PBS with 10\% Block Ace 1:2,000) (Cappel Laboratories, Cochranville, Pa.). Color was developed after another series of washes with substrate solution containing DAB in 100 $\mathrm{mM}$ Tris ( $\mathrm{pH}$ 8.5).

\section{Isolation and identification of virulent R. equi from feces of} foals

Fecal samples from the 13 Thoroughbred foals on the farm were collected 6 to 11 times after birth from March to August, 1998. For the selective isolation of $R$. equi, nalidixic acid-novobiocin-actidione (cycloheximide)-potassium tellurite (NANAT) medium, previously described by Woolcock et al. [33], was used. One gram of feces or soil sample was diluted serially with a 10-fold volume of sterile saline. Each diluent was inoculated onto two plates of NANAT medium, and the plates were incubated at $30^{\circ} \mathrm{C}$ for 2 or 3 days. All suspected colonies of $R$. equi were counted and the number of viable organisms per gram of feces or soil was calculated [27]. Two to ten colonies per specimen were subcultured, identified in our laboratory and then tested for the presence of 15- to 17$\mathrm{kDa}$ antigens by immunoblotting and virulence plasmids by agarose gel electrophoresis, as described previously [30].

Plasmid DNA was isolated from $R$. equi by the alkaline lysis method [3], with some modifications, as described previously [30]. Samples of the plasmid preparations were separated along with the plasmids of $R$. equi 96B6 (an 87-kb type II plasmid) and L1 (a 90-kb type I plasmid) in $0.7 \%$ agarose gel at approximately $5 \mathrm{~V} / \mathrm{cm}$ for $2 \mathrm{hr}$ [31].

\section{Results}

Serum IgGa, IgGb, IgGc, IgG(T), IgM, and IgA antibody levels specific for Tween 20-extracted ATCC 6939 antigens in 13 foals on a horse-breeding farm with a persistent incidence of $R$. equi infection were measured during the first 20 weeks of life by ELISA. During the observation period, 8 (Nos. 2-6, 8, 9 and 13)
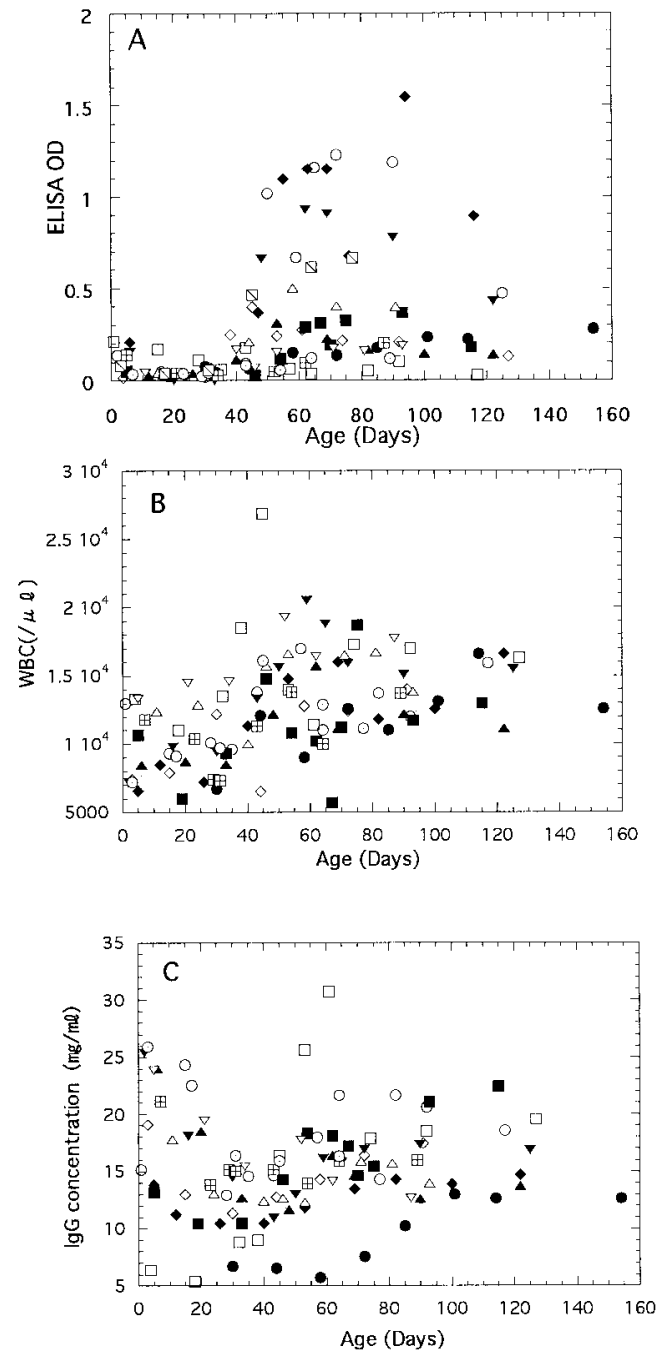

Fig. 1. ELISA titers against $R$. equi ATCC 6939 Tween 20-extracted antigens in the 13 foal sera obtained between 0 to 20 weeks after birth on the farm (A). WBC counts of the 13 foals (B). IgG concentrations of the 13 foals

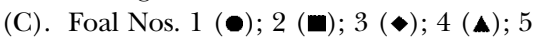
$(\mathbf{\nabla}) ; 6(\mathrm{C}) ; 7(\square) ; 8(\diamond) ; 9(\triangle) ; 10(\nabla) ; 11$ $(\boxplus) ; 12(\odot) ; 13(\Xi)$.

of the 13 foals showed a $>0.3$ OD value against ATCC 6939 antigen in a routine ELISA (anti-horse IgG) (Fig. $1 \mathrm{~A})$, which was tentatively fixed to be positive on the basis of readings made of healthy horse sera in previous studies. Four (Nos. 2, 6, 8 and 13) of them showed clinical signs and then were treated with antibiotics. The remaining 5 foals (Nos. $1,7,10,11$ and 12) had an OD value less than 0.3 , but 2 (Nos. 10 and 11) of them showed signs of temporal pyrexia. 

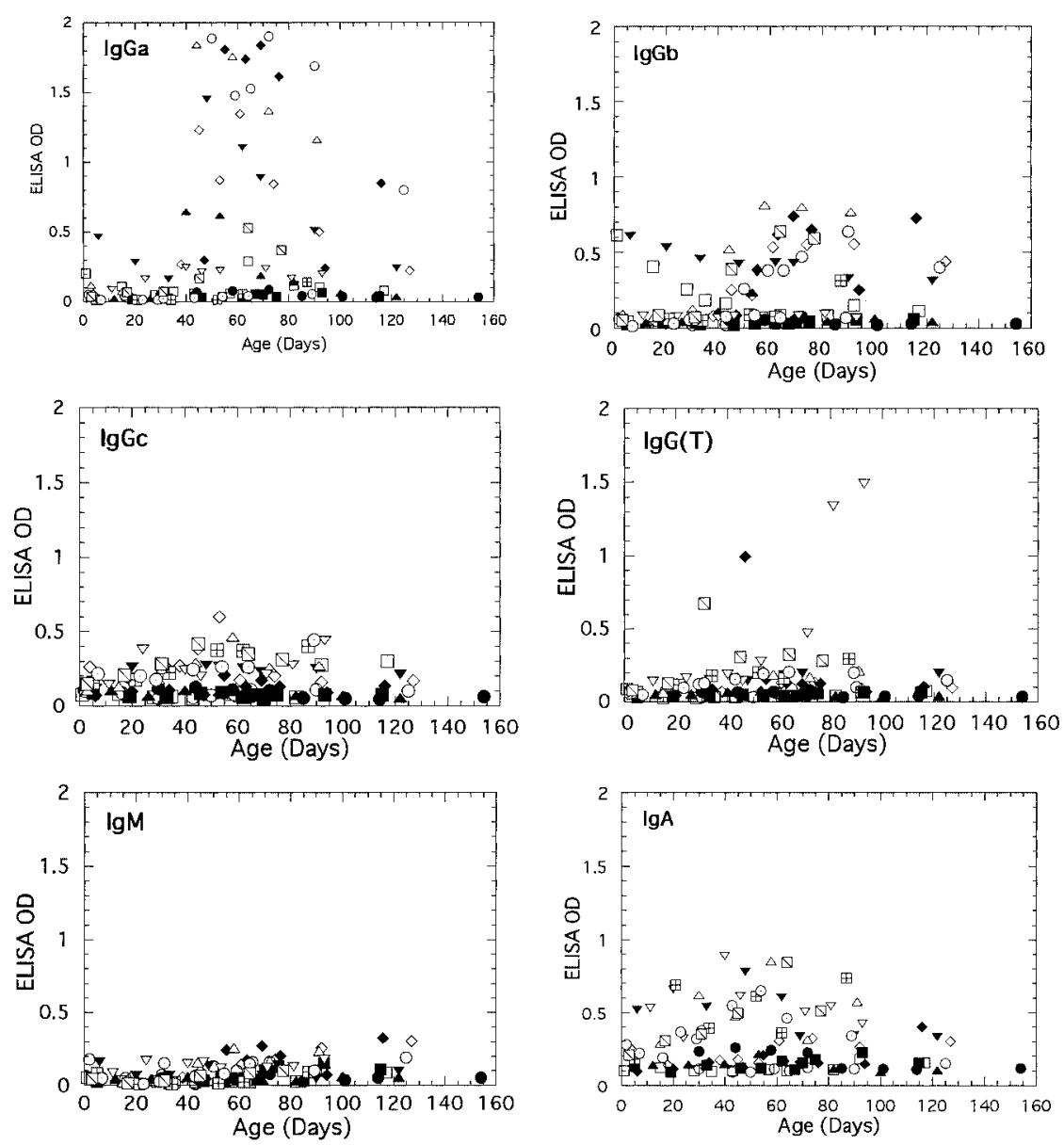

Fig. 2. ELISA titers of $R$. equi specific $\operatorname{IgGa}$, IgGb, $\operatorname{IgGc}$, $\operatorname{IgG}(\mathrm{T})$, IgM and $\operatorname{IgA}$ isotypes in serum of the 13 foals collected between 0 to 20 weeks after birth on the farm. Foal

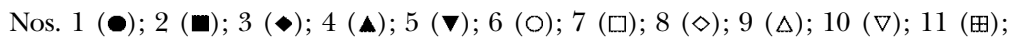
$12(\odot) ; 13(\square)$.

The results of isotype-specific antibody responses were analyzed according to age and are shown in Fig. 2. $R$. equi-specific IgGa was predominantly detected in the 6 foals (Nos. 3-6, 8 and 9) at 6 to 10 weeks after birth by ELISA with Tween 20-extracted ATCC 6939 antigens. Specific serum IgGb (foal Nos. 3, 6, 8, 9 and 13) and IgA (foal Nos. 5, 9-13) were also detected, but they showed much lower titers than IgGa antibodies. Specific $\operatorname{IgG}(\mathrm{T})$, IgGc and $\operatorname{IgM}$ were present consistently at low levels in most foals. Low antibody responses were observed in foals Nos. 1, 11 and 12.

Western immunoblot analysis of sera from all the foals for whole cells of virulent $R$. equi ATCC 33701 was done with a set of monoclonal antibodies [18]. IgGa and IgGb antibodies specific to VapA were detected by immunoblotting 5 to 7 weeks after birth in correlation with age in most foals except foal No. 13. Fig. 3 shows one of the typical results obtained from foal No. 3. In addition to specific IgGa and IgGb responses, foals Nos. 2 and 11 had $\operatorname{IgGc}$ and $\operatorname{IgG}(\mathrm{T})$ antibodies specific to

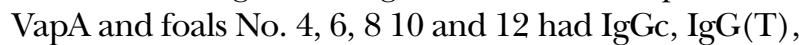
IgA and IgM antibodies specific to VapA detected by immunoblotting.

WBC counts increased to $15,000 / \mathrm{mm}^{3}$ or more by 6 to 8 weeks in accordance with the age and then decreased in most foals (Fig. 1B). Out of the 13 foals, 2 foals (Nos. 1 and 7) had a serum IgG concentration less than $1,000 \mathrm{mg} / \mathrm{d} l(650$ to $900 \mathrm{mg} / \mathrm{d} l)$ in the first week after birth, and their serum IgG concentrations gradually increased to 1,200 to $1,500 \mathrm{mg} / \mathrm{d} l$ by 20 weeks 


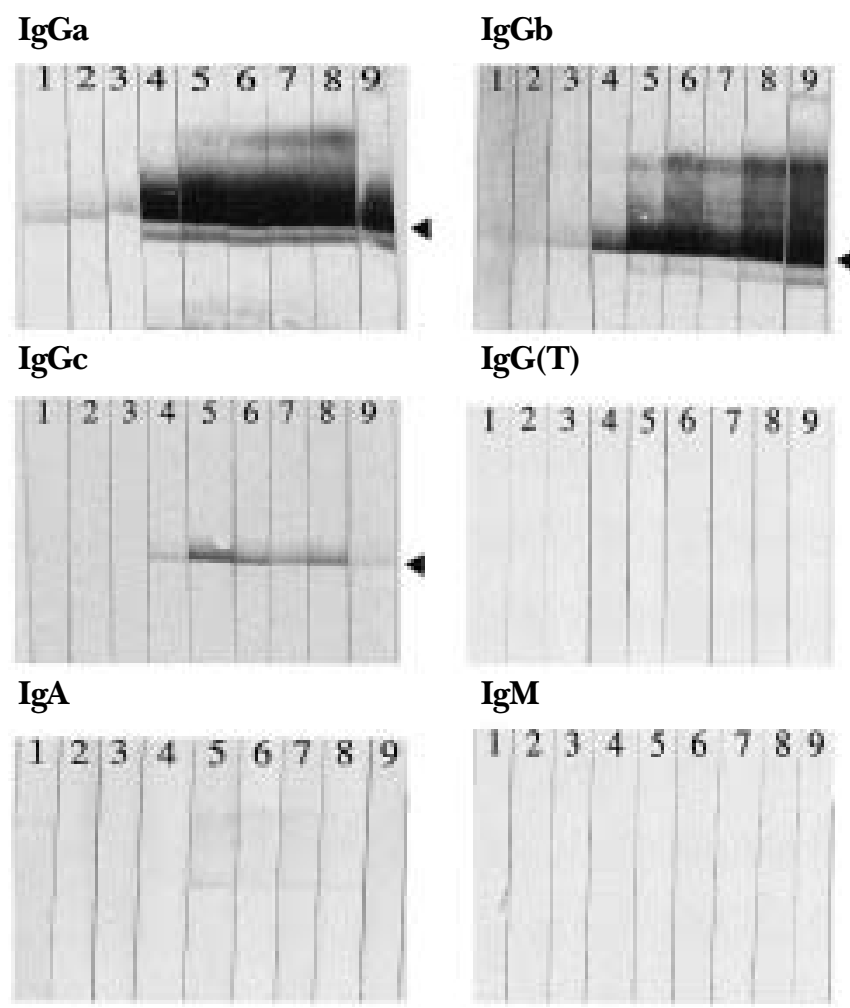

Fig. 3. Western immunoblot analysis of sera collected from foal No. 3 at 6 to 94 days old to whole cells of virulent $R$. equi. The arrowhead on the right indicates the 15 - to $17-\mathrm{kDa}$ antigens. Lanes 1, 6 days old; 2, 20 days old; 3, 34 days old; 4, 47 days old; 5,55 days old; 6,63 days old; 7,69 days old; 8,76 days old; 9 , 94 days old.

of age (Fig. 1C). On the other hand, serum IgG concentrations of the remaining 10 foals at first week of life were 1,500 to $2,500 \mathrm{mg} / \mathrm{d} l$ and decreased to 1,000 $\mathrm{mg} / \mathrm{d} l$ by 3 to 6 weeks of age, and then gradually increased.

Virulent R. equi was isolated from the feces of 13 foals at prevalence ranging from 12.5 to $55.6 \%$. Of 840 isolates from the 13 foals, $172(20.5 \%)$ isolates were virulent $R$. equi. Of the 172 virulent $R$. equi, 94 (48.8\%) contained an $87-\mathrm{kb}$ type II plasmid and $88(51.2 \%)$ contained a $90-\mathrm{kb}$ type I plasmid.

\section{Discussion}

The present study revealed that IgGa antibody specific to ATCC 6393 antigens was predominantly measured by ELISA and specific IgGa and IgGb antibodies to VapA were detected by immunoblotting in foals naturally exposed to $R$. equi on a farm with a persistent inhabitance of this organism. In Streptococcus equi (S. equi) and equine herpes virus 1 infections, IgGb or IgGa and IgGb were the predominant serum antibodies after natural infection $[14,16]$. In humans, protein antigens generally stimulate IgG1 and IgG3 response $[11,12,18]$, whereas polysaccharide antigens stimulate mainly IgG2 antibodies [1]. In mice, carbohydrate antigens preferentially elicit IgG3 response [17]. In contrast, IgG1 is the dominant response to protein antigens [17]. Our antigens for ELISA are soluble extracts from ATCC 6939 with Tween 20, so they may consist of capsular antigens and surface proteins of avirulent $R$. equi. On the other hand, VapA is a protein antigen which does not exist in avirulent $R$. equi [23]. We cannot yet explain the discrepancy in the results obtained from the ELISA and Western immunoblotting. It is possible that the properties of antigens used in both tests are responsible 
for the difference in the isotype-specific responses.

Little is known about the variation in the isotypespecific antibody response in horses due to the nature of antigen, the route of entry, and the form in which it reaches to the immune system. A difference in serum antibody responses in vaccinated horses from those in spontanous infection has been reported $[6,14,16]$. The levels of specific IgGa for S. equi were higher during and shortly after the infection, but they were very low in vaccinated horses [16]. Strong nasal IgA and serum IgGa, IgGb and IgA responses to influenza virus followed natural infection, whereas vaccinated animals showed only nasal and serum $\operatorname{IgG}(\mathrm{T})$ response [6]. The protective role of antibodies to the virulenceassociated antigens of $R$. equi has been described in a mouse model [32]. The protective effect of immune plasma has also been demonstrated in experimentally and naturally infected foals $[9,10]$. It might be interesting to investigate the isotype-specific antibody levels of equine hyperimmune sera or plasma and murine sera collected from mice immunized against virulent $R$. equi to study the function of IgG isotypes in the protection against $R$. equi infection.

$B$ cells secrete IgM antibodies specific for the inducing antigen. As their response to the antigen continues, these immunoglobulin-producing B cells switch their heavy chain constant region production from $\mu$ to $\gamma, \varepsilon$, or $\alpha$ while retaining their original variable regions. In that way, they produce immunoglobulins of difference classes without altering their antigen specificity. In this study, we observed very low IgM antibody response prior to those in IgGa, IgGb, and IgA by means of ELISA and immunoblotting. With the same assays, strong $R$. equi specific IgM antibody response was observed in the foals experimentally infected with $R$. equi [25]. We cannot yet explain the difference between the IgM responses observed in the naturally exposed foals and those in the experimentally infected foals. The properties of antigens such as Tindependent or -dependent, and their routes of entry such as oral or intratracheal invasion, might affect the immune response in those foals.

Recently, a complete sequence of virulence plasmid p33701 that encodes a family of seven closely related virulence-associated proteins designated VapA and VapC to VapH has been shown. VapC, -D, and -E are secreted proteins coordinatedly regulated by temperature with VapA [23]. Serum from foals infected with $R$. equi recognized either recombinant VapD or rVapE [5]. Further studies are needed to clarify the isotype specific response to Vap proteins by using peptide antigens and recombinant proteins in naturally and experimentally infected foals and vaccinated foals.

R. equi is a soil organism that is ingested into the gut of many herbivores and is widespread in their environment [2]. Virulent R. equi showing VapA has been isolated from soil or horses at many horsebreeding farms having endemic infection [20-22, 28]. In the present study, all of the foals tested shed virulent $R$. equi in their feces at various concentrations. This means that all foals were exposed to virulent $R$. equi by inhalation and ingestion. In natural and experimental $R$. equi infection, foals often do not show any clinical changes until the later stages of the disease [34]. In our previous study [7], we demonstrated that foals having high OD values of over 0.9 in serum (total $\operatorname{IgG}$ ) had high leukocyte counts and fibrinogen and alphaglobulin values. In accordance with the number of $R$. equi in their feces and aging, WBC counts increased in all foals with or without clinical signs. These results suggest that the foals studied might be naturally exposed to virulent $R$. equi repeatedly or continuously with various doses, and develop antibodies to the VapA without any clinical manifestations.

\section{Acknowledgments}

This study was supported by a grant-in-aid from the Equine Research Institute, Japan Racing Association, by a grant-in-aid for general scientific research (1 2460140) from the Ministry of Education, Science and Culture, Japan, and by a grant-in-aid for scientific research $(2000,2001)$ from the School of Veterinary Medicine and Animal Sciences, Kitasato University.

\section{References}

1. Barrett, D.J. and Ayoub, E.M. 1986. IgG2 subclass restriction of antibody to pneumococcal polysaccharides. Clin. Exp. Immunol. 63: 127-134.

2. Barton, M.D. and Hughes, K.L. 1980. Corynebacterium equi: a review. Vet. Bull. 50: 65-80.

3. Birnboim, H.C. and Doly, J. 1979. A rapid alkaline extraction procedure for screening recombinant plasmid DNA. Nucleic Acids Res. 7: 1513-1523.

4. Burton, D.R. and Woof, J.M. 1992. Human antibody effecter function. Adv. Immunol. 51: 1-84. 
5. Byrne, B.A., Prescott, J.F., Palmer, G.H., Takai, S., Nicholson, V.M., Alperin, D.C., and Hines, S.A. 2001. The virulence plasmid of Rhodococcus equi contains an inducible gene family encoding secreted protein. Infect. Immun. 69: 650-656.

6. Hannant, D., Jessett, D.M., O'Neill, T., and Mumford, J.A. 1989. Antibody isotype responses in the serum and respiratory tract to primary and secondary infections with equine influenza virus (H3N8). Vet. Microbiol. 19: 293-303.

7. Higuchi, T., Hashikura, S., Gojo, C., Inui, T., Satoh, S., Yoshida, M., Ishiyama, T., Yamada, H., and Takai, S. 1997. Clinical evaluation of the serodiagnostic value of enzyme-linked immunosorbent assay for Rhodococcus equi in foals. Equine Vet. J. 29: 274-278.

8. Jefferis, R. and Kumararatne, D.S. 1990. Selective IgG subclass deficiency: quantification and clinical relevance. Clin. Exp. Immunol. 81: 357-367.

9. Madigan, J.E., Hietala, S.K., and Muller, N. 1991. Protection against naturally acquired Rhodococcus equi pneumonia in foals by administration of hyperimmune plasma. J. Reprod. Fertil. Suppl. 44: 571-578.

10. Martens, R.J., Martens, J.G., Fiske, R.A., and Hietala, S.K. 1989. Rhodococcus equi foal pneumonia: protective effects of immune plasma in experimentally infected foals. Equine Vet. J. 21: 249-255.

11. Morell, A., Roth-Wicky, B., and Skvaril, F. 1983. Immunoglobulin $\mathrm{G}$ subclass restriction of antibodies against hepatitis B surface antigen. Infect. Immun. 39: 565-568.

12. Mortimer, G.E. and Widdowson, J.P. 1979. Predominance of immunoglobulin G sub-class 3 among the complement-fixing antibodies to streptococcal M-associated protein. Clin. Exp. Immunol. 37: 247-258.

13. Prescott, J.F. 1991. Rhodococcus equi: an animal and human pathogen. Clin. Microbiol. Rev. 4: 20-34.

14. Ruitenberg, K.M., Love, D.N., Gilkerson, J.R., Wellington, J.E., and Whalley, J.M. 2000. Equine herpesvirus 1 (EHV-1) glycoprotein D DNA inoculation in horses with pre-existing EHV-1/ EHV-4 antibody. Vet. Microbiol. 76: 117-127.

15. Sheoran, A.S. and Holmes, M.A. 1996. Separation of equine IgG subclasses (IgGa, IgGb and IgG(T)) using their differential binding characteristics for staphylococcal protein A and streptococcal protein G. Vet Immunol. Immunopathol. 55: 33-43.

16. Sheoran, A.S., Sponseller, B.T., Holmes, M.A., and Timoney, J.F. 1997. Serum and mucosal antibody isotype responses to M-like protein ( $\mathrm{SeM}$ ) of Streptococcus equi in convalescent and vaccinated horses. Vet. Immunol. Immunopathol. 59: 239-251.

17. Slack, J., Der-Balian, G.P., Nahm, M., and Davie, J.M. 1980. Subclass restriction of murine antibodies. II. The IgG plaque-forming cell response to thymus-independent type 1 and type 2 antigens in normal mice and mice expressing an X-linked immunodeficiency. J. Exp. Med. 151: 853862.

18. Stevens, R., Dichek, D., Keld, B., and Heiner, D. 1983. IgG1 is the predominant subclass of in vivoand in vitro- produced anti-tetanus toxoid antibodies and also serves as the membrane IgG molecule for delivering inhibitory signals to antitetanus toxoid antibody-producing B cells. J. Clin. Immunol. 3: 65-69.

19. Sugiura, T., Kondo, T., Imagawa, H., and Kamada, M. 1998. Production of monoclonal antibodies to six isotypes of horse immunoglobulin. Vet. Immunol. Immunopathol. 62: 145-151.

20. Takai, S. 1997. Epidemiology of Rhodococcus equi infections. Vet. Microbiol. 56: 167-176.

21. Takai, S., Anzai, T., Yamaguchi, Y., Kakizaki, K, Takahagi, J., Sato, Y., Takehara, F., Tamada, Y., Matsukura, S., Tani, A., Kato, M., Seno, N., Sasaki, Y., Tsubaki, S., and Kamada, M. 1994. Prevalence of virulence plasmids in environmental isolates of Rhodococcus equi from horse-breeding farms in Hidaka, Hokkaido. J. Equine Sci. 5: 21-25.

22. Takai, S., Hidaka, D., Fujii, M., Shindoh, Y., Murata, T., Nakanishi, S., Sasaki, Y., Tsubaki, S., and Kamada, M. 1996. Serum antibody responses of foals to virulence-associated 15- to 17-kilodalton antigens of Rhodococcus equi. Vet. Microbiol. 52: 6371.

23. Takai, S., Hines, S., Sekizaki, T., Nicholson, V.M., Alperin, D., Osaki, M., Takamatsu, D., Nakamura, M., Suzuki, K., Ogino, N., Kakuda, T., Dan, H., and Prescott, J.F. 2000. DNA sequence and comparison of virulence plasmids from Rhodococcus equi ATCC 33701 and 103. Infect. Immun. 68: 6840-6847.

24. Takai, S., Kawazu, S., and Tsubaki, S. 1985. Enzyme-linked immunosorbent assay for diagnosis of Corynebacterium (Rhodococcus) equi infection in foal. Am. J. Vet. Res. 46: 2166-2170.

25. Takai, S., Kawazu, S., and Tsubaki, S. 1986. Immunoglobulin and specific antibody responses to Rhodococcus (Corynebacterium) equi infection as measured by enzyme-linked Immunosorbent assay. J. Clin. Microbiol. 23: 943-947. 
26. Takai, S., Koike, K., Ohbushi, S., Izumi, C., and Tsubaki, S. 1991. Identification of 15- to 17kilodalton antigens associated with virulent Rhodococcus equi. J. Clin. Microbiol. 29: 439-443.

27. Takai, S., Narita, K., Ando, K., and Tsubaki, S. 1986. Ecology of Rhodococcus (Corynebacterium) equi in soil on a horse-breeding farm. Vet. Microbiol. 12: 169-177.

28. Takai, S., Ohbushi, S., Koike, K, Tsubaki, S., Oishi, H., and Kamada, M. 1991. Prevalence of virulent Rhodococcus equi in isolates from soil and feces of horses from horse-breeding farms with and without endemic infections. J. Clin. Microbiol. 29: 2887-2889.

29. Takai, S., Ohkura, H., Watanabe, S., and Tsubaki, S. 1986. Quantative aspects of fecal Rhodococcus (Corynebacterium) equi in foals. J. Clin. Microbiol. 23: 794-796.

30. Takai, S., Sekizaki, T., Ozawa, T., Sugawara, T., Watanabe, Y., and Tsubaki, S. 1991. Association between a large plasmid and 15- to 17-kilodalton antigens in virulent Rhodococcus equi. Infect. Immun. 59: 4056-4060.

31. Takai, S., Shoda, M., Sasaki, Y., Tsubaki, S., Fortier, G., Pronost, S., Rahal, K., Becu, T., Begg, A., Browning, G., Nicholson, V.M., and Prescott, J.F. 1999. Genetic analysis of virulent Rhodococcus equi based on restriction fragment length polymorphism of virulence plasmids: A molecular approach for epidemiology of virulent $R$. equi in the world. J. Clin. Microbiol. 37: 3417-3420.

32. Tan, C., Prescott, J.F., Patterson, M.C., and Nicholson, V.M. 1995. Molecular characterization of a lipid-modified virulence-associated protein of Rhodococcus equi and its potential in protective immunity. Can. J. Vet. Res. 59: 51-59.

33. Woolcock, J.B., Farmer, A.M.T., and Mutimer, M.D. 1979. Selective medium for Corynebacterium equi isolation. J. Clin. Microbiol. 9: 640-642.

34. Yager, J.A. 1987. The pathogenesis of Rhodococcus equi pneumonia in foals. Vet. Microbiol. 14: 225232. 